\title{
CARDIOVASCULAR DISEASE RISK ASSESSMENT WITH HIGH-SENSITIVITY CARDIAC TROPONIN I AND OTHER BIOMARKERS: AN OBSERVATIONAL COHORT STUDY IN JOHOR, MALAYSIA
}

\author{
J Sickan ${ }^{1 *}, \mathrm{TC} \mathrm{Aw}^{2}$, Shaoqing X Du${ }^{1}, \mathrm{~J} \mathrm{Li}^{1}, \mathrm{H}$ Janel${ }^{1}$ and A Beshiri ${ }^{1}$ \\ ${ }^{1}$ Abbott Diagnostics, Singapore \\ ${ }^{2}$ Department of Laboratory Medicine, Changi General Hospital, Singapore.
}

*Corresponding author: Jaganathan Sickan

Email: Jaganathan.sickan@abbott.com

\begin{abstract}
Although cardiovascular disease (CVD) is a major health challenge in Malaysia, many Malaysians are unaware of their CVD risk. The measurement of biomarkers in the general population may help to identify at-risk individuals before the onset of symptomatic CVD. The aim of this community health screening project was to determine the distribution of high-sensitivity troponin I (hsTnl) and other biomarkers of CVD risk in the general population of Johor, Malaysia. A sampling of self-declared healthy volunteers was conducted during the 2016 Kembara Mahkota community event in Johor. Levels of hsTnl, B-type natriuretic peptide (BNP) and homocysteine (HCY) were analyzed using the ARCHITECT immunoassay and clinical chemistry platforms utilizing fresh venous blood samples. Based on previous data, biomarker levels indicative of high risk were $>10$ and $>12 \mathrm{ng} / \mathrm{mL}$ for hsTnl in women and men, respectively, BNP $>50 \mathrm{pg} / \mathrm{mL}$ in the overall population, and $\mathrm{HCY}>13.6 \mu \mathrm{mol} / \mathrm{L}$ in women and $>16.2 \mu \mathrm{mol} / \mathrm{L}$ in men. A total of 2744 volunteers participated in biomarker testing. Biomarker measurements showed that up to $10 \%$ of participants had moderate or high CVD risk based on hsTnl, approximately $2 \%$ were above the BNP threshold and $>50 \%$ of subjects were above the HCY threshold. General population biomarker testing shows distribution of biomarker levels that may be indicative of CVD risk or the presence of disease and suggests that biomarker-guided risk strategies should be more widely implemented to determine the impact they would have on early detection and prevention of disease.
\end{abstract}

Key words: biomarkers, B-type natriuretic peptide, cardiovascular disease, homocysteine, troponin, Malaysia; risk classification, screening

\section{INTRODUCTION}

The increasing prevalence non-communicable diseases (NCDs) represents a key health challenge in Malaysia, with NCDs causing more deaths than all other causes combined. ${ }^{1-3}$ Cardiovascular disease (CVD) is particularly problematic, developing at a relatively young age and accounting for $36 \%$ of all deaths in Malaysia in 2012. ${ }^{1-4}$

Most cases of CVD can be prevented, but many Malaysians have undiagnosed CVD risk factors and remain unaware of their increased CVD risk. ${ }^{5,6}$ These patients often go on to present with latestage coronary heart disease (CHD), heart failure (HF) or major adverse CV events, such as myocardial infarction (MI) and stroke. ${ }^{1-4,6}$ It is therefore important to encourage participation in health checks for CVD prevention.5,6 However, CVD screening in Malaysia is mainly performed opportunistically by healthcare providers or is initiated by the individual, and the uptake of health checks is low. ${ }^{5}$ Furthermore, the subclinical cardiac dysfunction that precedes HF and other CVD is often undiagnosed because of a lack of screening and testing strategies. ${ }^{7}$ The measurement of biomarkers in the general population may help to identify at-risk individuals for timely intervention and prevention before the onset of clinically detectable risk factors or symptomatic CVD. ${ }^{7,8}$

To obtain clear local NCD risk data in the general population of Johor, Malaysia, we conducted a community-based project in which members of public were encouraged to undergo blood-based biomarker tests to screen for risk of various NCDs. Here, we report the results of the CVD arm of the project, in which high-sensitivity troponin I (hsTnl), B-type natriuretic peptide (BNP) and homocysteine (HCY) levels were measured to assess distribution of the population with previously reported risk thresholds. ${ }^{9-20}$ Results of screening for other NCDs (type 2 diabetes, cancer and thyroid disease) will be reported separately.

\section{MATERIALS AND METHODS}

General population screening was conducted during the Kembara Mahkota event, which took place from the $14^{\text {th }}$ to the $17^{\text {th }}$ of May 2016. The Kembara Mahkota is a royal "meet the people" tour that covers the 10 districts of the state of Johor. A total of 2744 individuals over the age of 18 volunteered for biomarker testing at the event. They were briefed by district healthcare personnel, and asked basic questions regarding their medical, surgical and family disease history. All volunteers were free of known CVD based on self-declaration. Collected venous blood samples 
were anonymized and then transported to KPJ Johor Specialist Hospital for analysis.

This study was part of a Johor State government community service project that was approved and conducted by the Johor State Health Department. All participants gave informed consent. Fresh blood sample analyses were performed daily at Johor Specialist Hospital. All hsTnl, BNP and HCY analyses were performed on the Abbott ARCHITECT immune assay and clinical chemistry system. Levels of hsTnl $>10 \mathrm{ng} / \mathrm{L}$ in women and $>12 \mathrm{ng} / \mathrm{L}$ in men were considered to be indicative of a high risk of CVD, 4-10 and 6-12 ng/L, respectively were considered moderate risk, whereas readings of $<4 \mathrm{ng} / \mathrm{L}$ in women and $<6 \mathrm{ng} / \mathrm{L}$ in men were considered low risk. ${ }^{11,12,16,17,20}$ In the overall population, BNP $>50 \mathrm{pg} / \mathrm{mL}$ was considered to be indicative of risk of $\mathrm{HF}$, and BNP $>100 \mathrm{pg} / \mathrm{mL}$ indicated high risk of HF. ${ }^{10,14,15}$ Levels of $\mathrm{HCY}>13.6 \mu \mathrm{mol} / \mathrm{L}$ in women and $>16.2 \mu \mathrm{mol} / \mathrm{L}$ in men were considered to be indicative of risk of CVD. $9,13,18,19$

\section{RESULTS}

\section{Subject characteristics}

Individuals who took part in biomarker screening $(n=2744)$ were aged between 18 and > 80 years old; subject to sample availability, each of the three cardiovascular biomarkers of interest was measured in a minimum of 2716 participants. Most participants (93\%) were $<60$ years old, and $50.6 \%$ were female (Table I).

Table I. Demographic characteristics of the screened population

\begin{tabular}{|c|c|}
\hline Characteristics & $\begin{array}{l}\text { Total } \\
(\mathrm{N}=2716)\end{array}$ \\
\hline \multicolumn{2}{|l|}{ Gender, n/N (\%) } \\
\hline Female & 1489 / 2716 \\
\hline Male & 1227 / 2716 \\
\hline \multicolumn{2}{|l|}{ Age and gender, n/N (\%) } \\
\hline Females Aged $<60$ years & 1393 / 1489 \\
\hline Females Aged $\geq 60$ years & $96 / 1489$ (6\%) \\
\hline Males Aged $<60$ years & 1097 / 1227 \\
\hline Males Aged $\geq 60$ years & $130 \ddot{j} 1227$ \\
\hline
\end{tabular}

The distribution of biomarker risk categories is shown in Figure 1. Based on hsTnl measurements, $1.1 \%$ of women and $3.4 \%$ of men were considered to be at high risk for CV events, $1.1 \%$ of women and $6.9 \%$ of men were at moderate risk, and $92.8 \%$ of women and $89.6 \%$ of men were considered low risk. The BNP level was $>50 \mathrm{pg} / \mathrm{mL}$, indicating a risk of future $\mathrm{HF}$, in $3.2 \%$ of the population, and a BNP level $>100 \mathrm{pg} / \mathrm{mL}$, indicating high risk of HF, was present in $0.8 \%$. HCY levels were indicative of CVD risk in $55.2 \%$ of women and $54.3 \%$ of men.

Median biomarker levels are shown in Table II. The interquartile range and $90^{\text {th }}, 95^{\text {th }}$ and $99^{\text {th }}$ percentile values indicate that levels of BNP and hsTnl were not normally distributed but skewed towards the lower end of the range.

Table II. Median (interquartile range) cardiovascular biomarker levels, along with $90^{\text {th }}, 95^{\text {th }}$ and $99^{\text {th }}$ percentiles

\begin{tabular}{|c|c|c|c|}
\hline & $\begin{array}{l}\mathrm{BNP}, \\
\mathrm{pg} / \mathrm{mL}\end{array}$ & $\begin{array}{l}\text { hsTnl, } \\
\text { ng/L }\end{array}$ & $\begin{array}{c}\text { Homocysteine, } \\
\mu \mathrm{mol} / \mathrm{L}\end{array}$ \\
\hline $\begin{array}{l}\text { Median } \\
\text { (IQR) }\end{array}$ & $\begin{array}{c}11.0 \\
(10.0- \\
19.0)\end{array}$ & $\begin{array}{c}1.4 \\
(0.8- \\
2.5)\end{array}$ & $16.6(7.4-29.9)$ \\
\hline $\begin{array}{l}90^{\text {th }} \\
\text { percentile }\end{array}$ & 30.0 & 4.6 & 41.4 \\
\hline $\begin{array}{l}95^{\text {th }} \\
\text { percentile }\end{array}$ & 42.0 & 7.0 & 46.9 \\
\hline $\begin{array}{l}99^{\text {th }} \\
\text { percentile }\end{array}$ & 83.0 & 19.0 & 50.0 \\
\hline
\end{tabular}

$I Q R$, interquartile range

Mean and median levels of each individual biomarker tended to increase with age, peaking in patients aged 70 to 79 years (Table III and Figure 2 ), but did not vary significantly between men and women (Table III and Figure 3). The fact that most participants were under the age of 60 years may have influenced the distribution of hsTnl concentrations. 
(a)

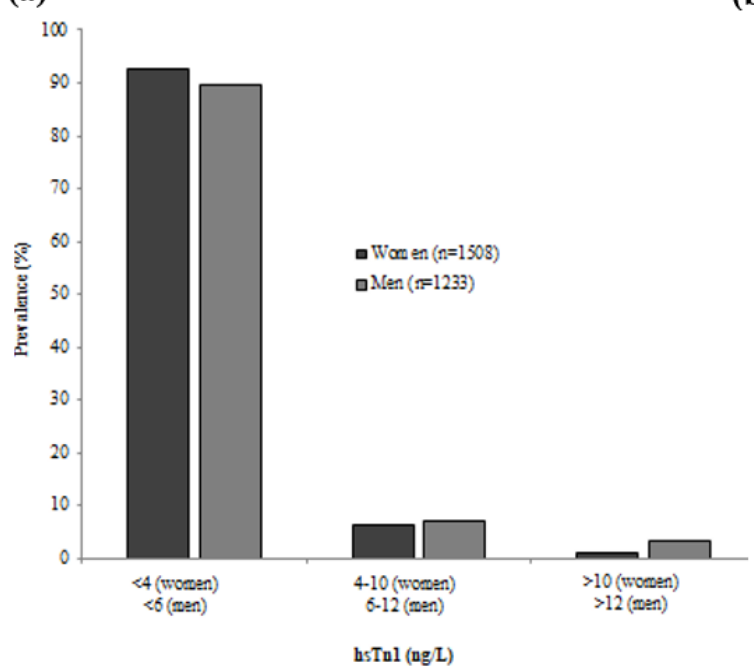

(c) (b)

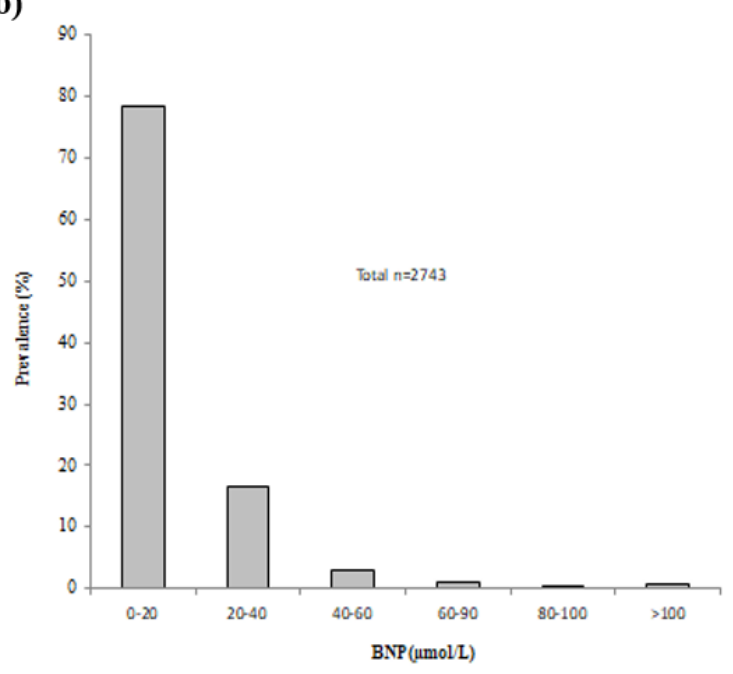

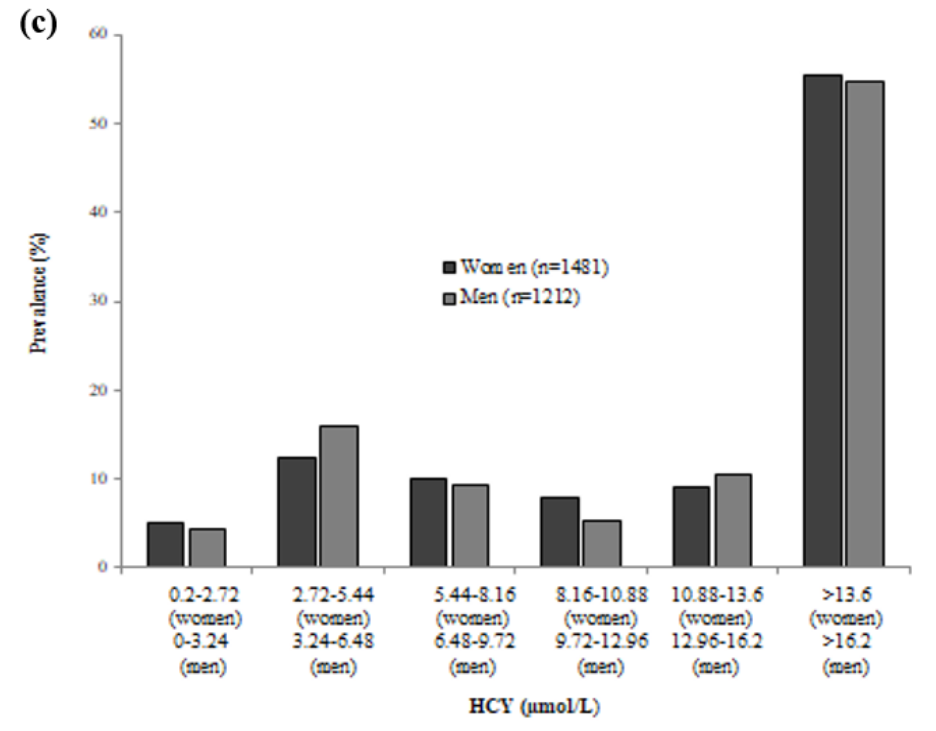

Figure 1. Distribution of CVD biomarker levels in the general population: (a) HsTNnl, high-sensitivity troponin-I; (b) BNP, B-type natriuretic peptide; and (c) HCY, homocysteine.

Table III. Mean and median (range) biomarker values in specific population subgroups

\begin{tabular}{|c|c|c|c|c|c|c|}
\hline \multirow{2}{*}{$\begin{array}{l}\text { Participant } \\
\text { subgroup }\end{array}$} & \multicolumn{2}{|c|}{ BNP, pg/mL } & \multicolumn{2}{|c|}{ hsTnl, ng/L } & \multicolumn{2}{|c|}{ Homocysteine, $\mu \mathrm{mol} / \mathrm{L}$} \\
\hline & Mean & $\begin{array}{l}\text { Median } \\
\text { (Range) }\end{array}$ & Mean & Median (Range) & Mean & Median (Range) \\
\hline \multicolumn{7}{|l|}{ Gender } \\
\hline Females & 19.02 & $13(3-485)$ & 1.74 & $0.6(0-166.8)$ & 19.01 & $15.4(1.1-50)$ \\
\hline $\begin{array}{l}\text { Males } \\
\text { Age groups }\end{array}$ & 16.39 & $10(9-536)$ & 3.49 & $1.1(0-153.2)$ & 20.79 & $17.9(1.1-50)$ \\
\hline $\begin{array}{l}<20 \text { years } \\
20-29 \text { years } \\
30-39 \text { years } \\
40-49 \text { years } \\
50-59 \text { years } \\
60-69 \text { years } \\
70-79 \text { years } \\
>80 \text { years }\end{array}$ & $\begin{array}{l}13.19 \\
14.67 \\
14.50 \\
16.53 \\
21.29 \\
28.04 \\
50.14 \\
25.20\end{array}$ & $\begin{array}{l}10(10-45) \\
10(3-108) \\
10(10-65) \\
11(8-139) \\
13(10-536) \\
18.5(9-301) \\
16(10-280) \\
18(10-51)\end{array}$ & $\begin{array}{l}1.26 \\
1.59 \\
1.73 \\
2.07 \\
3.64 \\
5.38 \\
6.01 \\
3.08\end{array}$ & $\begin{array}{l}0.9(0-5.5) \\
0.9(0-51.4) \\
1.1(0-89.4) \\
1.45(0-40.6) \\
1.2(0-166.8) \\
2.5(0.1-105.6) \\
3.8(1-22.7) \\
2.5(1.1-6.8)\end{array}$ & $\begin{array}{l}11.93 \\
15.80 \\
17.33 \\
20.44 \\
22.57 \\
27.69 \\
34.48 \\
13.36\end{array}$ & $\begin{array}{l}9.65(1.1-41.2) \\
12(1.2-50) \\
14.6(1.4-50) \\
18.5(1.3-50) \\
20.2(1.9-50) \\
26.8(1.1-50) \\
39.8(14.6-50) \\
18.6(3.5-20.7)\end{array}$ \\
\hline
\end{tabular}

$B N P, B$-type natriuretic peptide; hsTnl, high-sensitivity troponin I. 


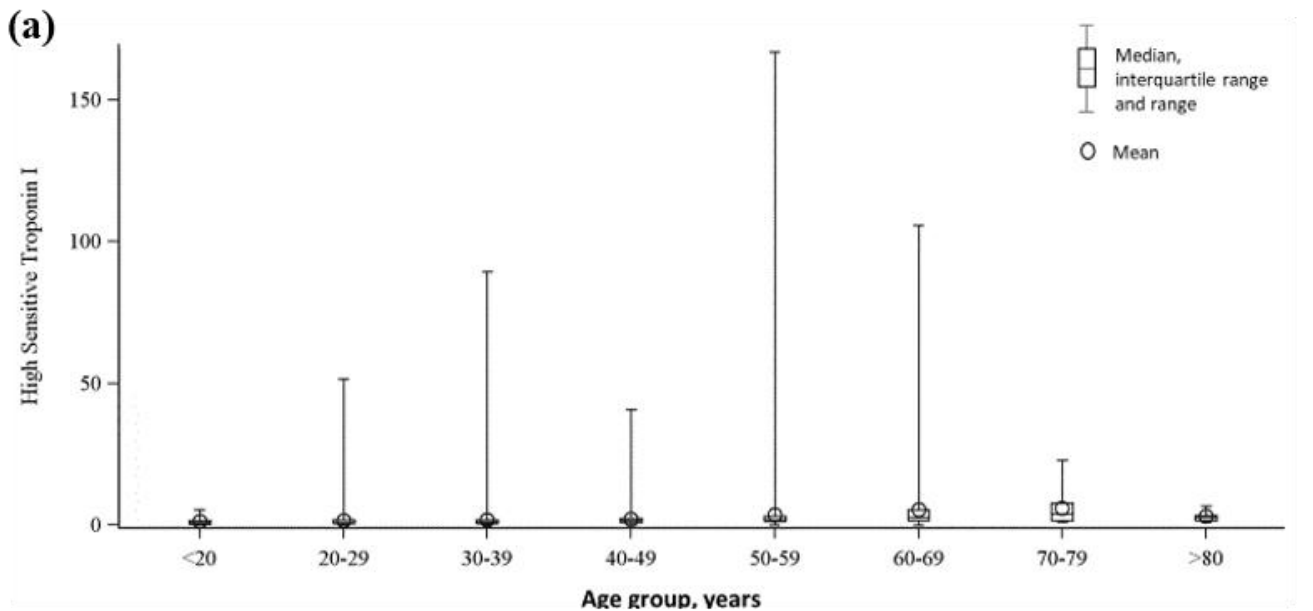

(b)

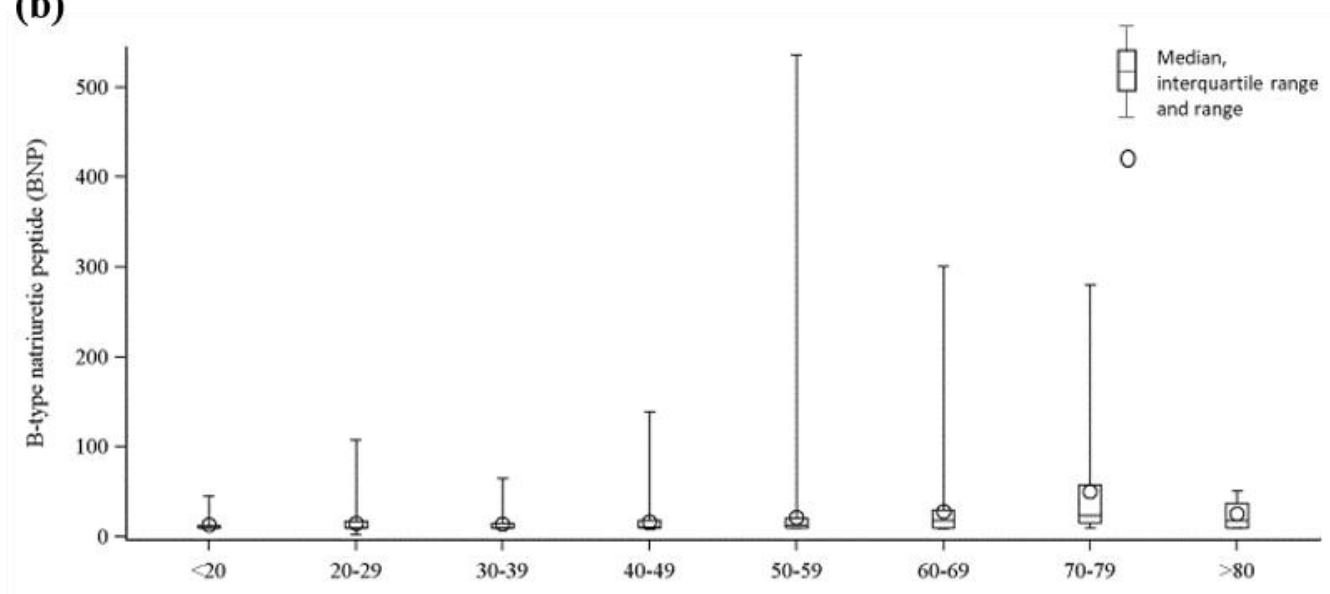

(c)

Age group, years

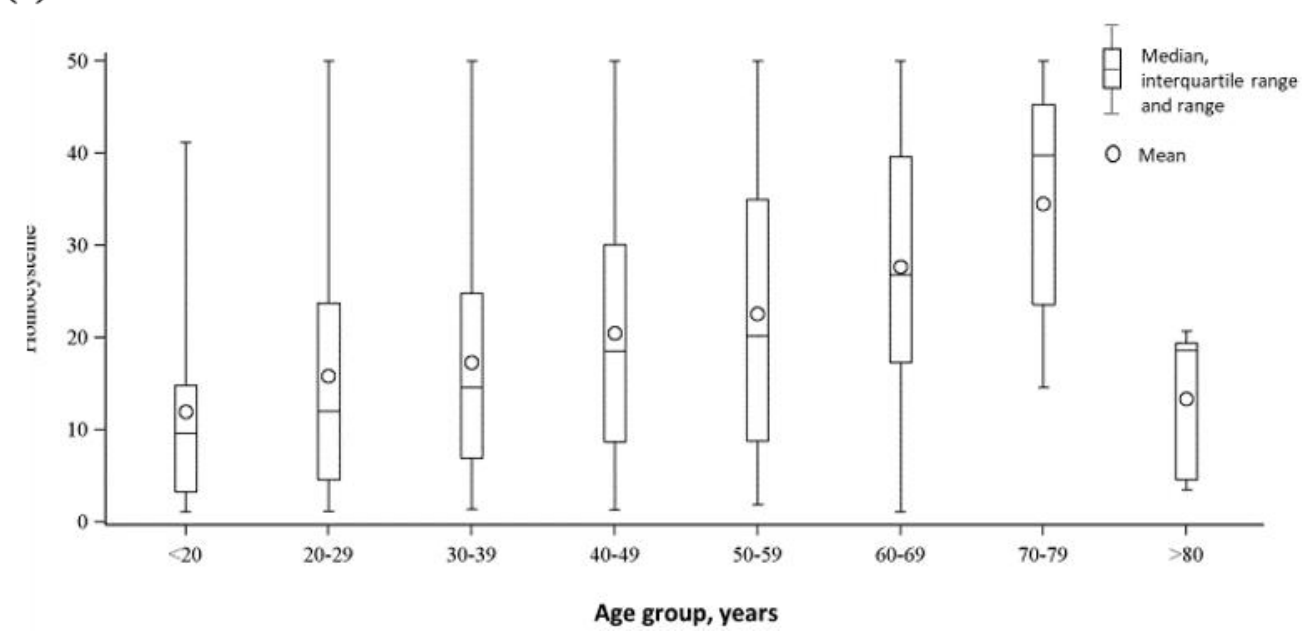

Figure 2. Levels of cardiovascular biomarkers in different age groups: (a) High-sensitivity troponin-I $(\mathrm{ng} / \mathrm{L})$; (b) B-type natriuretic peptide ( $\mu \mathrm{mol} / \mathrm{L}) ;(\mathrm{c})$ homocysteine $(\mu \mathrm{mol} / \mathrm{L})$. 

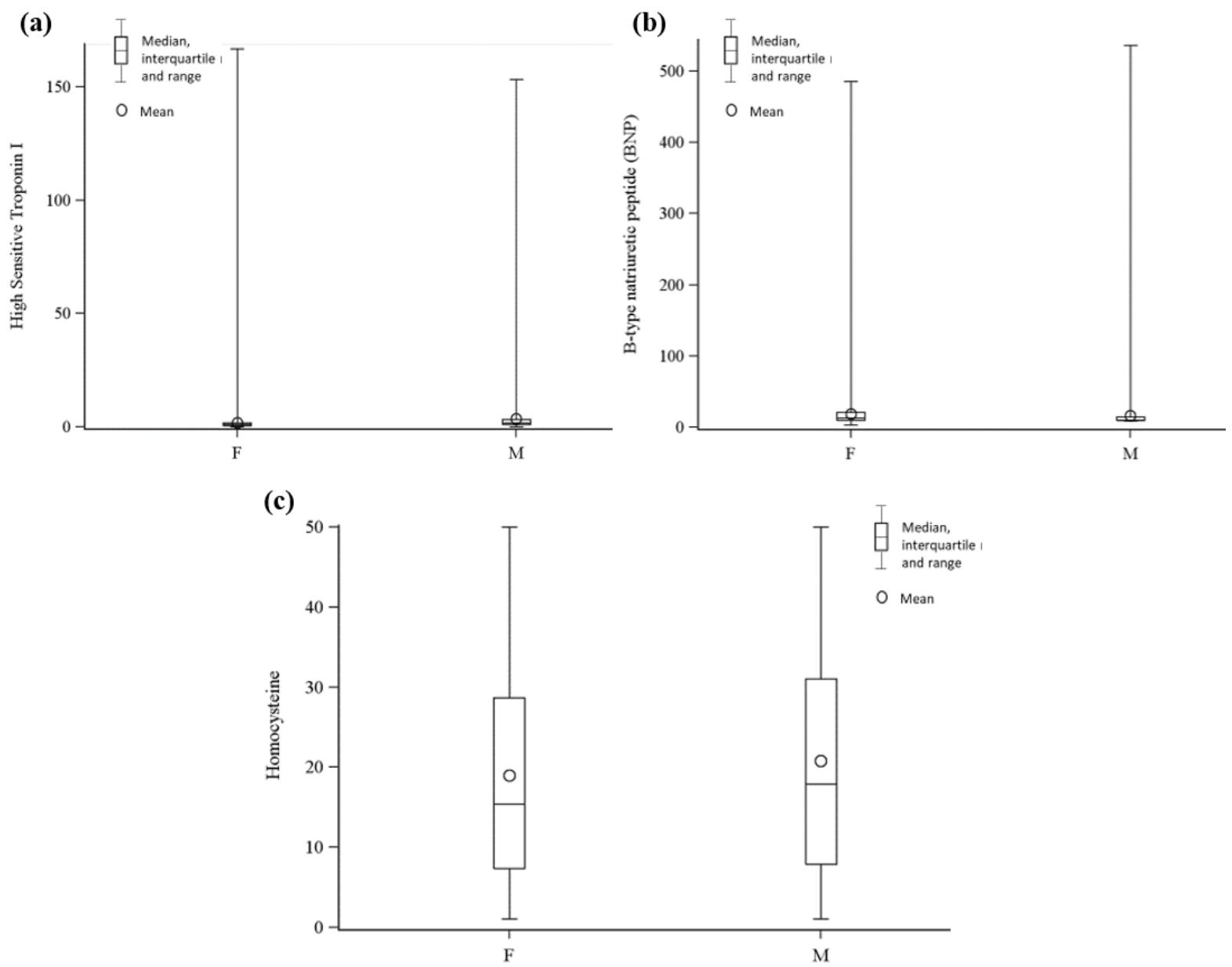

Figure 3. Cardiovascular biomarker levels in men and women: (a) High-sensitivity troponin-I (ng/L); (b) B-type natriuretic peptide ( $\mu \mathrm{mol} / \mathrm{L})$; (c) homocysteine $(\mu \mathrm{mol} / \mathrm{L})$. F: female; M: male.

Most individuals in the screened population had no or one elevated cardiovascular risk marker (Figure 4). The number of people with three elevated risk markers was $9(0.4 \%)$ using a BNP risk threshold of $>50 \mathrm{pg} / \mathrm{mL}$ and $5(0.2 \%)$ using a BNP risk threshold of $>100 \mathrm{pg} / \mathrm{mL}$ (Figure 4 ).

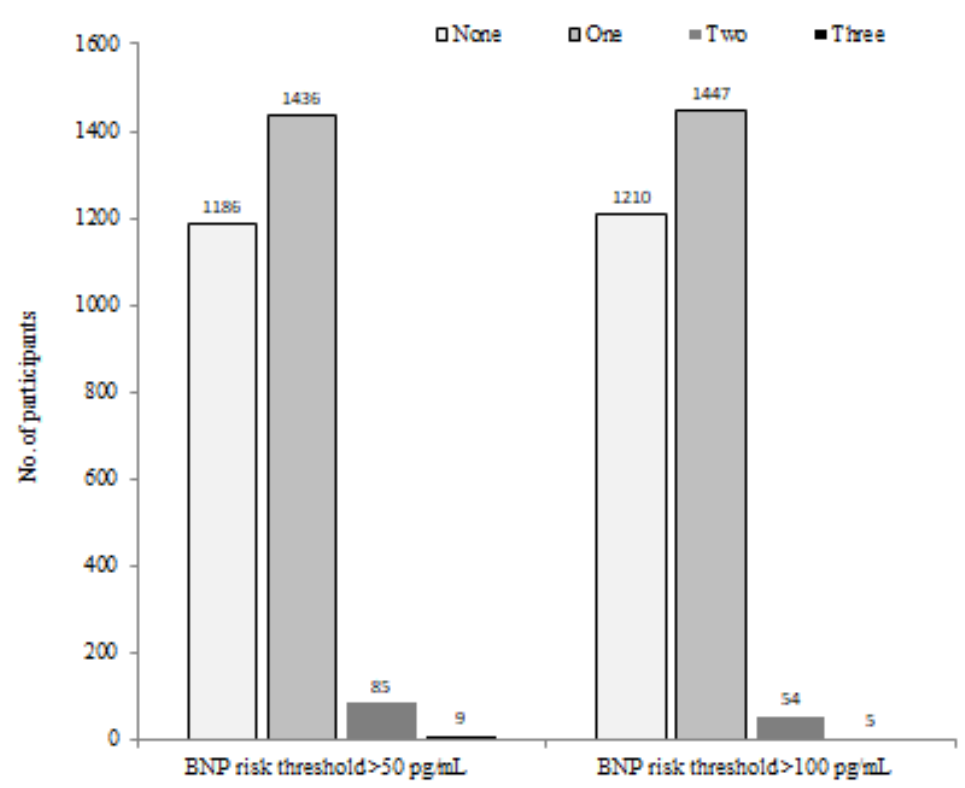

Figure 4. Distribution of participants by number of cardiovascular biomarkers showing an elevated risk stratified by B-type natriuretic peptide (BNP) threshold $>50 \mathrm{pg} / \mathrm{mL}$ or $>100 \mathrm{pg} / \mathrm{mL}$. 


\section{DISCUSSION}

The Kembara Mahkota event, which is traditionally well attended by a large crosssection of the community, provided an opportunity to identify individuals at high risk of CVD, and to improve awareness of CVD within the general Johor population. Information offered to people visiting our healthcare booth was aimed at improving awareness of disease and the importance of screening for early detection or prevention of disease. Consequently, 2744 individuals with no known CVD accepted our offer of blood-based biomarker testing to assess their disease risk.

It is important to identify individuals at risk of CVD, or early in the course of CVD, before they present with late-stage disease and diseaserelated complications. Although use of biomarkers to screen for CVD in the general population is not routinely performed, biomarkers have the potential to identify at-risk individuals for primary prevention earlier and more accurately than traditional screening strategies. ${ }^{8,21-23}$ It is likely that no single biomarker will be sensitive or specific enough to be used on its own, so we used a panel of three blood-based biomarkers (hsTnl, BNP and $\mathrm{HCY}$ ) to identify high-risk individuals that may not have been identified using traditional screening methods.

Once identified with the appropriate biomarker assays, high-risk individuals can be targeted for early intervention and prevention of symptomatic CVD. For example, compared with care guided by standard clinical assessment, significant reductions in $\mathrm{HF}$ and major adverse CV events have been reported in clinical trials using BNP assays to identify patients with CV risk factors at the highest risk of CVD who then received specialist primary preventative intervention. ${ }^{14,24}$ In our project, we utilized biomarkers indicative of ischemic damage, myocardial stretch and general CVD risk to stratify the subjects and this may be a strategy to consider when utilizing biomarkers for risk stratification.

Cardiac troponin and natriuretic peptide biomarkers are associated with long-term risk of major adverse $\mathrm{CV}$ events and $\mathrm{HF}$ in the general population. ${ }^{8,20-21,23,25} \mathrm{hsTnl}$ and BNP were chosen for our panel of CVD risk biomarkers because they are well established independent and complementary assays that facilitate the detection of subclinical cardiac disease and increased CV risk before the onset of clinically detectable risk factors. $8,20,26,27 \mathrm{HCY}$ is a novel biomarker that is considered an independent predictor of CV events in low- and high-risk populations, and elevated levels of $\mathrm{HCY}$ are associated with increased risk of $\mathrm{CHD}$ in the general population. ${ }^{18,28,29}$
It has been demonstrated that factors such as age and gender are associated with circulating $\mathrm{BNP}^{33}$, $\mathrm{HCY}^{34}$, and $\mathrm{hsTnl}^{35}$. However, the aim of this observational study was to determine the $\mathrm{CV}$ risk profile of the general healthy population of Johor, Malaysia, using these biomarkers, to aid the development of screening strategies specific to the local population. It is noteworthy that there is a continuous association between CV risk and levels of BNP, hsTNI and HCY, and while there are no precisely-defined cut-offs for these biomarkers ${ }^{14,25-26,29,31}$, the cut-off levels interpreted as being indicative of the highest risk of CV events (hsTnl $>10 \mathrm{ng} / \mathrm{L}$ in women and $>12$ $\mathrm{ng} / \mathrm{L}$ in men), HF (BNP>50 pg/ml) and CHD (HCY $>13.6 \mu \mathrm{mol} / \mathrm{L}$ in women and $>16.2 \mu \mathrm{mol} / \mathrm{L}$ in men) in this study were based on Abbott biomarker assay sensitivities and evidence-based values that are now utilised in clinical guidelines. ${ }^{14-16,26,30,31,36}$ Indeed, Maisel et al. demonstrated that BNP at threshold of $50 \mathrm{pg} / \mathrm{ml}$ has a negative predictive value of $96 \%$ for heart failure, while the diagnostic accuracy of BNP at cut-off of $100 \mathrm{pg} / \mathrm{ml}$ was $83.4 \%{ }^{15}$ Additionally, Sigurdardottir et al. ${ }^{37}$ recently showed that the addition of hsTnl to established $\mathrm{CV}$ risk prediction models led to a net reclassification improvement that was superior to that of C-reactive protein. These studies support the threshold values of the specified CV biomarkers that were utilised in this study.

In our study, approximately $1-3 \%$ of the population were identified as being at the highest risk of having a CV event or developing HF based on hsTnl and BNP assay results. In comparison, previously published studies in general American and German populations have reported troponin levels $>10$ $\mathrm{ng} / \mathrm{L}$ in $1.5 \%$ to $7.3 \%$ of individuals. ${ }^{22,32}$ The age and ethnic mix of general populations may translate into differences in circulating cardiac troponin levels, with lower levels in younger and/or predominantly Chinese populations. ${ }^{22,32}$

Compared with our hsTnl and BNP results, high proportions (>50\%) of men and women were classified as high-risk for CHD on the basis of their HCY level. Whereas hsTnl and BNP are very specific biomarkers for cardiac problems, ${ }^{7,25,26}$ plasma HCY levels are increased by a wide range of factors, including certain lifestyle factors, vitamin deficiencies and drugs, ${ }^{13,25}$ which may have contributed to this result.

\section{CONCLUSION}

We believe that to effectively reduce the incidence and improve the prognosis of CVD in Malaysia, projects such as ours are required to raise disease awareness and encourage seemingly healthy individuals to participate in biomarker disease screening programmes so that high-risk individuals can be identified and offered timely intervention and prevention. Overall, using a multi-biomarker approach, more than $50 \%$ of our self-declared healthy population were identified 
as being potentially at risk of CVD. Further studies with follow-up are required to assess whether interventions to reduce $\mathrm{CV}$ risk have an impact on outcomes in these individuals.

\section{ACKNOWLEDGMENTS}

This community health project was organised by Abbott Diagnostics. All biomarker assays and reagents were provided by Abbott Diagnostics. The authors thank the Royal Palace of Johor, the Kembara Mahkota event organizers, staff from Johor Specialist Hospital, Puteri Hospital and staff from the Ministry of Health Malaysia for their partnership and support. Medical writing support was provided by MIMS Pte Ltd and was funded by Abbott Diagnostics. The authors were fully responsible for all content and editorial decisions, were involved at all stages of manuscript development, and have approved the final version.

\section{REFERENCES}

1. Institute for Public Health. National Health and Morbidity Survey 2015 (NHMS 2015). Volume II: Non-communicable diseases, risk factors and other health problems. Kuala Lumpur, Malaysia: Ministry of Health Malaysia; 2015.

2. Low WY, Lee YK, Samy AL. Noncommunicable diseases in the Asia-Pacific region: Prevalence, risk factors and community-based prevention. Int J Occup Med Environ Health 2015; 28(1): 20-26. Doi:10.2478/s13382-014-0326-0

3. Wan Ahmad WA, Kui-Hian S, editors. Annual Report of the Percutaneous Coronary Intervention (PCI) Registry. 2010 - 2012. Kuala Lumpur: National Heart Association of Malaysia (NHAM) and the Ministry of Health Malaysia; 2013.

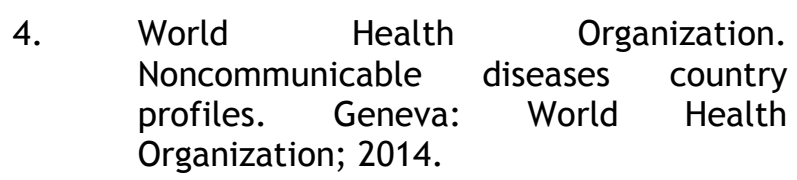

5. Cheong AT, Khoo EM, Tong SF, Liew SM. To Check or Not to Check? A Qualitative Study on How the Public Decides on Health Checks for Cardiovascular Disease Prevention. PLoS One 2016; 11(7): e0159438.

Doi:10.1371/journal.pone.0159438

6. Yen ST, Tan AK, Mustapha FI. Awareness of diabetes, hypertension, and hypercholesterolemia in Malaysia. J Diabetes 2017; 9(9): 874-883. Doi:10.1111/1753-0407.12502
7. Shemisa K, Bhatt A, Cheeran D, Neeland IJ. Novel Biomarkers of Subclinical Cardiac Dysfunction in the General Population. Curr Heart Fail Rep 2017; 14(4): 301-310. doi:10.1007/s11897-0170342-z

8. McKie PM, AbouEzzeddine OF, Scott CG, Mehta R, Rodeheffer RJ, Redfield MM, Burnett JC Jr, Jaffe AS. High-sensitivity troponin I and amino-terminal pro--B-type natriuretic peptide predict heart failure and mortality in the general population. Clin Chem 2014; 60(9): 1225-1233. doi:10.1373/clinchem.2014.222778

9. Bostom AG, Silbershatz $H$, Rosenberg $I H$, Selhub J, D'Agostino RB, Wolf PA, Jacques PF, Wilson PW. Nonfasting plasma total homocysteine levels and all-cause and cardiovascular disease mortality in elderly Framingham men and women. Arch Intern Med 1999; 159(10): 1077 1080.

10. Doust JA, Glasziou PP, Pietrzak E, Dobson AJ. A systematic review of the diagnostic accuracy of natriuretic peptides for heart failure. Arch Intern Med 2004; 164(18): 1978-1984.

doi:10.1001/archinte.164.18.1978

11. Eggers KM, Johnson N, Lind L, Venge $P$, Lindahl B. Cardiac troponin I levels in an elderly population from the community the implications of sex. Clin Biochem 2015; 48(12): 751-756. doi:10.1016/j.clinbiochem.2015.04.013

12. Iribarren C, Chandra M, Rana JS, Hlatky MA, Fortmann SP, Quertermous T, Go AS. High-sensitivity cardiac troponin I and incident coronary heart disease among asymptomatic older adults. Heart 2016; 102(15): 1177-1182. doi:10.1136/heartjnl-2015-309136

13. Kim HJ, Kim MK, Kim JU, Ha HY, Choi BY. Major determinants of serum homocysteine concentrations in a Korean population. J Korean Med Sci 2010; 25(4): 509-516.

Doi:10.3346/jkms.2010.25.4.509

14. Ledwidge M, Gallagher J, Conlon C, Tallon E, O'Connell E, Dawkins I, Watson C, O'Hanion R, Bermingham M, Patle A, et al. Natriuretic peptide-based screening and collaborative care for heart failure: the STOP-HF randomized trial. JAMA 2013; 310(1): 66-74.

Doi:10.1001/jama.2013.7588

15. Maisel AS, Krishnaswamy P, Nowak RM, McCord J, Hollander JE, Duc P, Omland T, 
Storrow AB, Abraham WT, Wu AH, et al. Rapid measurement of $B$-type natriuretic peptide in the emergency diagnosis of heart failure. N Engl J Med 2002; 347(3): 161-167. doi: 10.1056/NEJMoa020233

16. Omland $\mathrm{T}$, de Lemos JA, Holmen OL, Dalen $\mathrm{H}$, Benth JŠ, Nygård $\mathrm{S}$, Hveem $\mathrm{K}$, Røsjø $\mathrm{H}$. Impact of sex on the prognostic value of high-sensitivity cardiac troponin I in the general population: the HUNT study. Clin Chem 2015; 61(4): 646-656. doi:10.1373/clinchem.2014.234369

17. Thorsteinsdottir I, Aspelund $\mathrm{T}$, Gudmundsson E, Eiriksdottir G, Harris TB, Launer LH, Gudnason V, Venge P. Highsensitivity cardiac troponin I is a strong predictor of cardiovascular events and mortality in the AGES-Reykjavik community-based cohort of older individuals Clin Chem 2016; 62(4): 62330. Doi:10.1373/clinchem.2015.250811

18. Veeranna V, Zalawadiya SK, Niraj A, Pradhan J, Ference B, Burack RC, Jacob S, Afonso L. Homocysteine and reclassification of cardiovascular disease risk. J Am Coll Cardiol 2011; 58(10): 10251033. doi:10.1016/j.jacc.2011.05.028

19. Whinecup PJ, Refsum H, Perry IJ, Morris $R$, Walker $M$, Lennon $L$, Thomson $A$, Ueland PM, Fbrahim SB. Serum total homocysteine and coronary heart disease: prospective study in middle aged men. Heart 1999; 82: 448-454.

20. Zeller $\mathrm{T}$, Tunstall-Pedoe $\mathrm{H}$, Saarela $\mathrm{O}$, Ojeda F, Schnabel RB, Tuovinen T, Woodward M, Struthers A, Hughes M, Kee $F$, et al. High population prevalence of cardiac troponin I measured by a highsensitivity assay and cardiovascular risk estimation: the MORGAM Biomarker Project Scottish Cohort. Eur Heart J 2014; 35(5): 271-281. doi:10.1093/eurheartj/eht406

21. AbouEzzeddine OF, McKie PM, Scott CG, Rodeheffer RJ, Chen HH, Michael Felker G, Jaffe AS, Burnett JC, Redfield MM. Biomarker-based risk prediction in the community. Eur J Heart Fail 2016; 18(11): 1342-1350. doi:10.1002/ejhf.663

22. Daniels LB, Clopton P, deFilippi CR, Sanchez OA, Bahrami H, Lima JA, Tracy RP, Siscovick D, Bertoni AG, Greenland P, Cushman M, Maisel AS, Criqui MH. Serial measurement of $\mathrm{N}$-terminal pro-B-type natriuretic peptide and cardiac troponin $T$ for cardiovascular disease risk assessment in the Multi-Ethnic Study of Atherosclerosis (MESA). Am Heart J 2015;
170(6):

$1170-1183$.

Doi:10.1016/j.ahj.2015.09.010

23. Gilstrap LG, Wang TJ. Biomarkers and cardiovascular risk assessment for primary prevention: an update. Clin Chem 2012; 58(1):

72-82.

doi:10.1373/clinchem.2011.165712

24. Huelsmann $M$, Neuhold $S$, Resl M, Strunk $\mathrm{G}$, Brath $\mathrm{H}$, Francesconi C, Adlbrecht $\mathrm{C}$, Prager R, Luger A, Pacher R, CLodi $M$. PONTIAC (NT-proBNP selected prevention of cardiac events in a population of diabetic patients without a history of cardiac disease): a prospective randomized controlled trial. J Am Coll Cardiol 2013; 62(15): 1365-1372. doi:10.1016/j.jacc.2013.05.069

25. Wang TJ, Larson MG, Levy D, Benjamin EJ, Leip EP, Omland T, Wolf PA, Vasan RS. Plasma natriuretic peptide levels and the risk of cardiovascular events and death. $\mathrm{N}$ Engl J Med 2004; 350(7): 655-663. doi:10.1056/NEJMoa031994

26. Blankenberg S, Salomaa V, Makarova N, Oieda F, Wild P, Lackner KJ, Jorgensen T, Thorand B, Peters A, Nauck $M$, Petersmann A, Vartiainen E, Veronesi G, Brambilla $\mathrm{P}$, Costanzo S, lacoviello $\mathrm{L}$, Linden G, Yarnell J, Patterson CC, Evertt $B M$, RIdker PM, Kontto J, Schnabel RB, Koenig W, Kee F, Zeller T, Kuulasmaa K, BiomarCARE Investigators. Troponin I and cardiovascular risk prediction in the general population: the BiomarCaRE consortium. Eur Heart J 2016; 37(30): 2428-2437.

Doi:10.1093/eurheartj/ehw172

27. Blankenberg $\mathrm{S}$, Zeller $\mathrm{T}$, Saarela $\mathrm{O}$, Havulinna AS, Kee F, Tunstall-Pedoe $\mathrm{H}$, Kuulasmaa K, Yarnell J, Schnabel RB, Wild PS, Munzel TF, Lackner KJ, Tiret L, Evans A, Salomaa V, MORGAM Project. Contribution of 30 biomarkers to 10 -year cardiovascular risk estimation in 2 population cohorts: the MONICA, risk, genetics, archiving, and monograph (MORGAM) biomarker project. Circulation 2010; 121(22): 2388-2397. Doi:10.1161/CIRCULATIONAHA.109.90141 3

28. Antoniades C, Antonopoulos AS, Tousoulis D, Marinou K, Stefanadis C. Homocysteine and coronary atherosclerosis: from folate fortification to the recent clinical trials. Eur Heart J 2009; 30(1): 6-15. Doi:10.1093/eurheartj/ehn515

29. Mallikethi-Reddy S, Briasoulis A, Akintoye $\mathrm{E}$, Afonso L. Novel biomarkers with potential for cardiovascular risk 
reclassification. Biomarkers 2017; 22(3-

4):

189-199.

Doi:10.1080/1354750X.2016.1201540

30. Apple FS, Collinson PO, IFCC Task Force on Clinical Applications of Cardiac Biomarkers. Analytical characteristics of high-sensitivity cardiac troponin assays. Clin Chem 2012; 58(1) :54-61. Doi:10.1373/clinchem.2011.165795

31. Wierzbicki AS. Homocysteine and cardiovascular disease: a review of the evidence. Diab Vasc Dis Res 2007; 4(2): 143-150. doi:10.3132/dvdr.2007.033

32. Leistner DM, Klotsche J, Pieper L, Stalla GK, Lehnert $\mathrm{H}$, Silber S, Marz W, Wittchen HU, Zeiher AM, DETECT Study Group. Circulating troponin as measured by a sensitive assay for cardiovascular risk assessment in primary prevention. Clin Chem 2012; 58(1): 200-208. doi:10.1373/clinchem.2011.174292

33. Redfield MM, Rodeheffer RJ, Jacobsen SJ, Mahoney DW, Bailey KR, Burnett JC Jr. Plasma brain natriuretic peptide concetration: impact of age and gender. J Am Coll Cardiol 2002; 40(5):976-982.

34. Kuo HK, Sorond FA, Chen JH, Hashmi A, Milberg WP, Lipsitz LA. The role of homocysteine in multisystem age-related problems: a systematic review. J Gerontol A Biol Sci Med Sci 2005; 60(9):1190-1201.

35. Eggers $K M$, Venge $P$, Lindahl $B$, Lind $L$. Cardiac Troponin I Levels Measured With a High-Sensitive Assay Increase Over Time and Are Strong Predictors of Mortality in an Elderly Population. J Am Coll Cardiol 2013; 61(18):1906-1913. doi:10.1016/j.jacc.2012.12.048

36. Yancy CW, Jessup M, Bozkurt B, Butler J, Casey DE Jr, Colvin MM, Drazner MH, Filippatos GS, Fonarow GC, Givertz MM, Hollenberg SM, Lindenfeld J, Masoudi FA, McBridge PE, Peterson PN, Stevenson LW, Westlake C. 2017 ACC/AHA/HFSA Focused Update of the 2013 ACCF/AHA Guideline for the Management of Heart Failure. J Am Coll Cardiol 2017; 70(6):776-803. Doi:10.1161/CIR.0000000000000509

37. Sigurdardottir FD, Lyngbakken $M N$, Holmen OL, Dalen H, Hveem K, Rosjo H, Omland T. Relative Prognostic Value of Cardiac Troponin I and C-Reactive Protein in the General Population (from the NordTrondelag Health [HUNT] Study). Am J Cardiol 2018; 121(8):949-955. doi:10.1016/j.amjcard.2018.01.004 